\title{
Survival in children requiring chronic renal replacement therapy
}

\author{
Nicholas C. Chesnaye ${ }^{1} \cdot$ Karlijn J. van Stralen $^{2} \cdot$ Marjolein Bonthuis $^{1}$ • \\ Jérôme Harambat ${ }^{3}$ - Jaap W. Groothoff ${ }^{4}$ - Kitty J. Jager ${ }^{1}$
}

Received: 14 December 2016 /Revised: 21 March 2017 / Accepted: 12 April 2017 /Published online: 15 May 2017

(C) The Author(s) 2017. This article is an open access publication

\begin{abstract}
Survival in the pediatric end-stage renal disease (ESRD) population has improved substantially over recent decades. Nonetheless, mortality remains at least 30 times higher than that of healthy peers. Patient survival is multifactorial and dependent on various patient and treatment characteristics and degree of economic welfare of the country in which a patient is treated. In this educational review, we aim to delineate current evidence regarding mortality risk in the pediatric ESRD population and provide pediatric nephrologists with up-to-date information required to counsel affected families.
\end{abstract}

Keywords End-stage renal disease $\cdot$ Mortality risk $\cdot$ Registry data $\cdot$ Global disparity $\cdot$ Outcomes $\cdot$ Children

\section{Introduction}

Approximately nine in every 1 million children $<20$ years of age in the developed world require renal replacement therapy

Nicholas C. Chesnaye

n.c.chesnaye@amc.uva.nl

1 ESPN/ERA-EDTA Registry, Department of Medical Informatics, Academic Medical Center, Amsterdam Public Health Research Institute, University of Amsterdam, Amsterdam, The Netherlands

2 Spaarne Gasthuis Academie, Spaarne Gasthuis, Hoofddorp, Netherlands

3 Department of Pediatrics, Bordeaux University Hospital and INSERM U1219, Bordeaux, France

4 Department of Pediatric Nephrology, Emma Children's Hospital AMC, Amsterdam, Netherlands
(RRT) treating end-stage renal disease (ESRD) [1]. Mortality risk in these children is multifactorial owing to the complex nature and multiple causes of ESRD in this population and is at least 30 times higher than that of healthy peers $[2,3]$. Although other patient-related outcomes, such as growth, psychosocial development, and quality of life (QoL) are of major importance, prolonging patient survival may be arguably the most relevant clinical goal. As ESRD in children is a rare condition, the statistical power needed to accurately assess (risk factors related to) survival has been limited. Over the past years, various (inter)national registries have provided sufficient data to advance epidemiological research and expand the evidence regarding outcomes and treatment guidelines for this population. In this review, we delineate the current evidence base regarding mortality risk in the pediatric RRT population and provide pediatric nephrologists with up-to-date data to counsel affected families.

\section{Improvements in patient survival}

Since the introduction of the first pediatric chronic RRT programs during the 1960s, substantial advances in renal medicine have been achieved (Table 1) [17, 18], and survival has improved significantly, especially in the youngest patients. Historic registry data from Australia and New Zealand (ANZDATA registry) cite a 10-year mortality rate of 110 deaths per 1000 patient-years during the 1960s, which was halved with each subsequent decade, stabilizing at 18 deaths per 1000 patient-years during the 1990s [19]. In European dialysis patients, the 5-year mortality risk decreased by $36 \%$ between 1980-1984 and 1995-2000 and by 79\% in the subgroup of patients aged 0-4 years [20]. In the USA, dialysis survival improved from 1990 to 2010, with each 5-year increment decreasing mortality by $12 \%$ in children $>5$ years and by 
Table 1 Key developments in renal medicine

\begin{tabular}{ll} 
Key developments & Year \\
\hline Hemodiafiltration [5] & 1967 \\
Portable PD devices [7] & $1970 \mathrm{~s}$ \\
Home HD programs [6] & 1971 \\
Continuous ambulatory peritoneal dialysis [4] & 1975 \\
On-line proportioning of bicarbonate buffer for dialysis [10] & 1977 \\
Addition of amino acids to dialysate [11] & $1980 \mathrm{~s}$ \\
Y-set catheter connection for PD [9] & 1983 \\
Recombinant human erythropoietin [12] & 1985 \\
Recombinant growth hormone therapy in children [13] & 1994 \\
Improved predialysis care [8] & Ongoing \\
Increased percentage of pre-emptive Tx [14] & Ongoing \\
Immunosuppressive drugs [15] & Ongoing \\
Nutrition [16] & Ongoing
\end{tabular}

$H D$ hemodialysis, $P D$ peritoneal dialysis, $T x$ transplantation.

$20 \%$ in children $<5$ years [21]. Most neonates and infants placed on dialysis now survive long enough to reach the minimum age and body weight required for successful transplantation $[22,23]$.

Posttransplant survival has also improved over time. The mortality risk in first renal transplant recipients in Europe decreased by $42 \%$ from 1995 to 2000 compared with 1980 to 1984 [20]. Between 1990 and 2010 in the USA, each additional calendar year led to a $3 \%$ decrease in mortality risk, which was $5 \%$ for children $<5$ years of age. Improvements were most pronounced during the first year posttransplant [24]. The 5year survival for deceased donor recipients improved from 91.2\% during $1987-1995$ to $96.4 \%$ during $2005-2013$ and from $95.1 \%$ to $97.1 \%$ for living-donor recipients [25]. The overall 5-year survival for pediatric RRT patients at present is $\sim 90 \%[3,26-30]$ and is similar across high-income countries (Table 2). In Europe, survival ranges from 82 to $96 \%$ at 10 years and from 76 to $89 \%$ at 20 years. Long-term survival probabilities for European patients are presented by age group and initial treatment modality in Table 3 (personal communication; ERA-EDTA Registry, 25 January 2017).

Table 2 Five-year crude survival probabilities of pediatric renal replacement therapy (RRT) patients by country and period

\begin{tabular}{lll}
\hline Country/area & Period & Survival \\
\hline Australia and New Zealand & $1963-2002$ & $83 \%$ \\
United States & $2004-2008$ & $89 \%$ \\
Canada & $1992-2007$ & $92 \%$ \\
Europe $^{1}$ & $2009-2011$ & $94 \%$ \\
Japan $^{2}$ & $2006-2011$ & $92 \%$ \\
Taiwan $^{2}$ & $1995-2004$ & $88 \%$ \\
\hline
\end{tabular}

${ }^{1}$ Four-year survival probability

${ }^{2}$ Incident dialysis patients only

\section{Factors associated with mortality}

\section{Age}

Age at dialysis initiation is a key determinant of patient survival. Registry data consistently shows that compared with adolescents, mortality risk is approximately four times higher in children $<5$ years of age at dialysis initiation, and 1.5 times higher in children $>5$ years of age $[3$, $19,21,31]$. Mortality risk remains the highest in neonatal and infant dialysis patients [31,32], who are technically challenging to treat due to small body size, a high risk of infection, difficulties in nutrition and growth, and a high prevalence of (severe) comorbidities [33, 34]. These challenges and a perceived unacceptable quality of life are important factors in the decision to withhold or withdraw treatment in some of these children [34-37]. Moreover, transplantation is often not feasible due to the small size of the child relative to the large donor kidney and is usually recommended after 18 months of age or $10 \mathrm{~kg}$. Growth retardation, which is highly prevalent in these children, further delays transplantation, and thus increases time on dialysis, which in turn increases mortality risk in this already vulnerable population $[34,38]$. Nonetheless, relatively good clinical outcomes have been reported, and survival has improved significantly in this group. An international collaboration recently demonstrated a 5 -year survival of $76 \%$ and a transplant probability of $55 \%$, concluding that relatively good survival may be achieved in neonates despite the high prevalence (73\%) of comorbidities [22].

Table 3 Long-term crude survival for patients beginning renal replacement therapy (RRT) between 1990 and 2014 by age group and initial treatment modality, using European Renal Association-European Dialysis and Transplant Association (ERA-EDTA) data for Austria, Bosnia and Herzegovina, Denmark, Spain, Finland, France, Greece, Iceland, The Netherlands, Norway, Romania, Serbia, Sweden, and Scotland (personal communication; Anneke Kramer, 25 January 2017)

\begin{tabular}{lcccc}
\hline & $5-\mathrm{yr}$ & $10-\mathrm{yr}$ & $15-\mathrm{yr}$ & $20-\mathrm{yr}$ \\
\hline Overall & $94 \%$ & $90 \%$ & $87 \%$ & $83 \%$ \\
Age & & & & \\
$0-1$ & $85 \%$ & $82 \%$ & $79 \%$ & $76 \%$ \\
$2-5$ & $92 \%$ & $88 \%$ & $83 \%$ & $81 \%$ \\
$6-12$ & $95 \%$ & $93 \%$ & $90 \%$ & $85 \%$ \\
$13-18$ & $95 \%$ & $92 \%$ & $88 \%$ & $85 \%$ \\
First RRT modality & & & \\
HD & $94 \%$ & $90 \%$ & $86 \%$ & $82 \%$ \\
PD & $92 \%$ & $88 \%$ & $85 \%$ & $82 \%$ \\
Tx & $97 \%$ & $96 \%$ & $93 \%$ & $89 \%$ \\
\hline
\end{tabular}

$H D$ hemodialysis, $P D$ peritoneal dialysis, $T x$ transplantation 


\section{Sex}

No studies have specifically investigated a possible effect of sex on mortality in the pediatric ESRD population, but girls seem to have a higher mortality risk than boys [2]. In the USA, girls $>5$ years of age on dialysis had a $27 \%$ increased mortality risk compared with boys, although this effect was less pronounced in younger children [21]. Girls had an 18\% higher cardiovascular-related and a $37 \%$ higher infection-related mortality risk compared with boys [39]. A potential explanation was suggested by a European study demonstrating a $23 \%$ decreased probability of pre-emptive transplantation in girls compared with boys. This disparity was mostly explained by the fact that girls tended to progress faster to ESRD and by differences in age and primary renal disease distribution. Other potential nonmedical factors, such as patient, parental, and physician attitudes toward transplantation, may also play a role [40].

\section{Race}

Race also affects mortality risk in the pediatric RRT population. In the USA, being black was associated with a $25 \%$ higher risk of death compared with being white in firsttransplant recipients [24] and a 64\% higher risk of death in dialysis patients. The likelihood of transplantation was also lower in both black and Hispanic patients [41]. Furthermore, black children were 1.6 times more likely to die from cardiovascular causes before they reached the age of 30 years compared with white children [42]. The former has been attributed to a higher incidence of hypertension, arrhythmia, cardiomyopathy, and valvular heart disease in blacks [43, 44]. Also, in CKD stages 1-3, black children were more likely to have elevated systolic and diastolic blood pressure than non-black children [45]. In Europe, black and Asian children were less likely to receive a transplant, and Asian children had a 2.5-fold higher mortality risk than white children [46]. Mortality risk was reduced after adjustment for primary renal disease, suggesting that differences in renal disease distribution between races explains part of these disparities.

\section{Primary renal disease}

Congenital anomalies of the kidney and urinary tract (CAKUT) and glomerulonephritis form the most common etiologies of renal disease in children, accounting for at least half of all pediatric ESRD patients [3,26]. Patients with CAKUT have the best survival probabilities of all primary renal disease groups, although survival varies by etiology $[21,32,47]$. In infants and neonates, those with renal hypo/dysplasia, congenital nephrotic syndrome, polycystic disease, and other/unknown manifestations had a 2- to 4times increased mortality risk compared with those with obstructive uropathy [23]. Poor patient survival has also been also described in patients with secondary glomerulonephritis, vasculitis, systemic lupus erythematosus, and primary hyperoxaluria [47-49].

\section{Anthropometry}

Children who are either underweight or obese at ESRD onset have an increased mortality risk. In the USA, this U-shaped association was seen in both dialysis and transplant patients, with mortality risk increasing by $26 \%$ for every 2 standard deviation (SD) increase or decrease from the 0.5 body mass index standard deviation score (BMI SDS) reference value [50]: in children with a high BMI, increased mortality risk may be due to volume overload, edema, or comorbidity; in underweight children, disease severity and malnutrition may be accountable. Low serum albumin $(<3.5 \mathrm{~g} / \mathrm{dl})$, a marker for malnutrition or inflammation, was indeed associated with a $90 \%$ increased risk of death [51]. Similarly, $\mathrm{Ku}$ et al. found that both obese (17\% increase) and underweight (26\% increase) children were at increased risk of mortality. Interestingly, they found that obese children were less likely to receive a transplant, especially from a living donor, and that this attenuated their increased mortality risk [52].

Growth failure in the pediatric RRT population may reflect disease severity and is associated with increased mortality [53]. In the USA, every SDS decrease in height increased mortality risk by $14 \%$. This effect was particularly evident in children $<14$ years of age but was similar across treatment modalities [50]. A report from North American Pediatric Renal Trials and Collaborative Studies (NAPRTCS) echoed these results, demonstrating that mortality risk was twice as high in children with a height SDS $<2.5$ compared with those of normal height [54]. Both short $(<3$ rd percentile) and tall ( $>3$ rd percentile) stature at RRT initiation were associated with an increased risk of death, although tall stature was seen only in a small group of white children with elevated BMI (>95th percentile) [55].

\section{Comorbidity}

Extrarenal comorbidity is common in the pediatric ESRD population. The UK Renal Registry reported that at the onset of RRT (2009-2013), 19.3\% of pediatric patients had at least one and $9.5 \%$ two or more comorbidities. Syndromic diagnosis (8\%), developmental delay (7\%), and congenital abnormality (7\%) were the most frequently reported [56]. Multiple studies show that comorbidity is an important predictor of mortality [21, 57], especially in patients with cognitive (5-year survival probability of $63 \%)$, cardiac (73\%), and pulmonary (50\%) abnormalities [58]. In a single-centre study from the UK, $76 \%$ of dialysis patients who died had a comorbid condition, resulting in a 7.5-times increased mortality than those without comorbidities [59]. Several 
studies show that youngest patients with co-morbid conditions have an increased mortality risk, especially those with pulmonary hypoplasia [60-63].

\section{RRT modality}

It is well established that (pre-emptive) renal transplantation offers better survival probabilities than does dialysis $[19,64]$. Nonetheless, $\sim 80 \%$ of pediatric patients are either started on dialysis to bridge the preparation time needed for transplantation or will require dialysis after graft loss [3]. Survival comparisons by dialysis modality in a randomized clinical trial (RCT) setting proved extremely difficult [65]. Consequently, survival comparisons remain reliant on observational studies $[21,27,51,66-68]$. In adults, there seems to be a consistent trend showing survival advantage during the first few years on peritoneal dialysis (PD), especially in younger, healthier, and nondiabetic patients [69-75]. In the pediatric dialysis population, recent registry data from Europe and the USA demonstrate a $21-32 \%$ reduced mortality risk in children who are started on PD [21, 66, 67]. In the USA, this treatment effect was only present in children $<5$ years, whereas in Europe, this effect was less pronounced in children $<5$ years and absent in infants $[21,66]$. Furthermore, European data show that this treatment effect was stronger during the first year of dialysis, in older children, and in children treated by nephrologist for a short period prior to starting dialysis (Fig. 1). As the latter may serve as a proxy for timely referral and speed of disease progression, it may prelude to indication bias due to unmeasured case-mix confounders, as sicker patients are more likely started on hemodialysis (HD) [66].

\section{Time on RRT}

Time spent on dialysis impacts mortality risk, which is highest during the first year of treatment and reflects the intrinsic

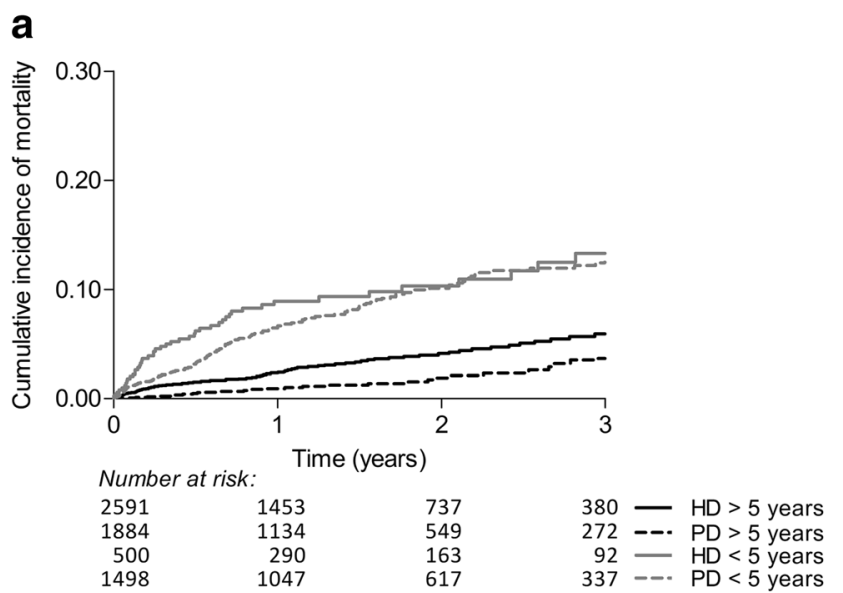

mortality risk of initiating dialysis. In the USA, mortality rates reach 48 per 1000 patient-years during the first month, peak during the second month at 57 , then slowly decrease to 28 during months 9-12. Mortality rates due to cardiovascular disease (CVD) and infection show similar patterns [76].

The length of time living with a functioning graft decreases patient mortality risk. In the USA, in first transplant recipients, mortality was highest during the first post-transplant year, after which the risk decreased (not significantly) by $1 \%$ for each additional follow-up year. This effect was stronger for cardiovascular-specific mortality, which decreased by $16 \%$ for each follow-up year, suggesting that transplantation has no cumulative negative effect on cardiovascular health in young recipients. However, returning to dialysis after graft failure was associated with a 4.4-fold increase in overall mortality risk and a 7.8-fold increase in cardiovascular mortality risk [39].

\section{Residual renal function}

In adult dialysis patients, a decrease in residual renal function has been associated with an increase in mortality risk [77, 78]. Data is lacking in the pediatric population. Two single-center US studies demonstrated that infants with oligoanuria had a higher mortality risk compared with infants with residual renal function [62,63], and others have demonstrated a positive effect of residual renal function on growth and nutrition [79-81].

\section{GFR at RRT initiation}

The literature discussing the relationship between glomerular filtration rate (GFR) at dialysis initiation and mortality risk in adults is conflicting [82-84], and this question has not yet been studied in children, although a study from the US found that children with a higher GFR at dialysis initiation had a

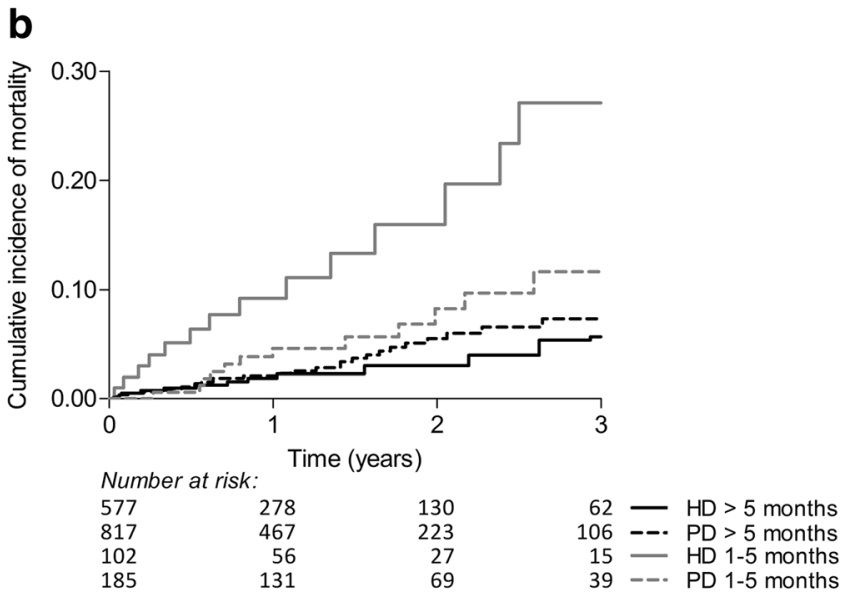

Fig. 1 Dialysis modality: a age group at renal replacement therapy initiation; -b time treated by a nephrologist. Reproduced with minor modification and permission [66]. $H D$ hemodialysis, $P D$ peritoneal dialysis 
decreased risk of hospitalization for hypertension and pulmonary edema [85]. A single RCT tackled this question in adults, finding no difference in survival between late and early starters, although the difference $\left(2.2 \mathrm{ml} / \mathrm{min} / 1.73 \mathrm{~m}^{2}\right)$ in GFR between groups was smaller than anticipated. Nonetheless, dialysis initiation was delayed by 6 months for late starters, which is favorable for both patients and costs [86].

\section{Causes of death}

\section{CVD and infection-related mortality}

CVD and infection-related mortality are the major causes of death in the pediatric RRT population, accountable for $\sim 30$ and $20 \%$, respectively, although rates vary strongly by country, age, race, definition used, and treatment modality [3, 42, $76,87]$. In Europe, infections were the leading cause of death in those on PD and those with a functioning graft, whereas cardiovascular causes dominated in patients on HD [3]. In the USA, a 4.5-times increased risk of CVD death in dialysis compared with transplant patients was reported [42]. In Australia and New Zealand, between 1963 and 2002, CVD accounted for 57\% and 43\% deaths in HD and PD patients, respectively, and $30 \%$ in those with a functioning transplant [19]. Both CVD and infection-related mortality have decreased over recent decades in the USA [21]. Vogelzang et al. studied changes in causes of death in adults on RRT since childhood in The Netherlands, finding that CVD mortality risk decreased by $91 \%$ since the 1970 s, whereas infection-related mortality risk doubled. The decrease in CVD mortality was attributed to increased awareness among nephrologists of the burden of CVD and a subsequent strict cardiovascular management in these patients [88].

\section{Malignancy-related mortality}

Malignancy-related death occurs more often in transplant recipients than in those on dialysis, likely caused by an impaired tumor immune surveillance due to immunosuppression $[2,39$, 89-91]. In Australia and New Zealand, malignancies accounted for $14 \%$ of deaths among transplant recipients, compared with only $1 \%$ and $2 \%$ among patients on HD and $\mathrm{PD}$, respectively, with most deaths occurring after 10 years of RRT [19]. Furthermore, pediatric transplant recipients had a 15- to 30-times increased risk of developing a malignancy compared with the general population [92]. In The Netherlands, 30 years after pediatric transplantation, $41 \%$ of survivors had developed cancer and $31 \%$ a second de novo cancer during the first year after initial diagnosis. Malignancies were responsible for $13 \%$ of all deaths in the cohort, and overall, malignancy was $>20$-fold higher than in the general population, with a notable increase in risk starting after 20 years of follow-up [93].

\section{International disparities in survival}

As economic welfare is a key determinant of health and access to health services, in low- and middle-income countries, providing chronic RRT is fraught with challenges. The complexity and cost involved in renal care, lack of financial and human resources, different health priorities, and inadequate health infrastructure have obvious consequences for access to RRT and survival probabilities of patients in these countries [94, 95]. In 2010, at least half of the 4.9 million people requiring RRT worldwide died prematurely because they did not have access to treatment [96]. Specifically in children, possibly $<10 \%$ of those requiring RRT have access to treatment, and most of these preventable deaths occurred in low- and middleincome countries [97]. The few studies available in lowerincome countries, where renal registries are often lacking, confirm these disparities. In Jamaica between 2001 and 2006, of all ESRD patients $<12$ years at diagnosis, $62.5 \%$ died due to restricted access to RRT [98]. In a tertiary hospital in South-West Nigeria between 2005 and 2012 the median survival time of 51 admitted pediatric ESRD patients was only 47 days. Of these, $82 \%$ had received an acute session of dialysis; however, continuation of RRT was not possible due to financial constraints, likely resulting in death shortly after discharge [99]. In two tertiary hospitals in Vietnam between 2001 and 2005 , only $27 \%$ of admitted pediatric ESRD patients received RRT. The remainder were treated conservatively due to a lack of financial resources [100]. In a tertiary care hospital in India, $61 \%$ of admitted pediatric ESRD patients were either treated conservatively or opted against further treatment due to the high cost of RRT, likely resulting in death [101]. As only a fraction of children requiring RRT globally actually receive treatment, and an equitable and universal provision of costly RRT is unrealistic in the short term, the largest gains in survival are likely to be made by delaying progression of CKD and preventing ESRD [94, 102].

Even among high- and middle-income countries, survival probabilities of pediatric RRT may vary. We recently demonstrated that considerable international variation exists in mortality rates across Europe, mostly attributable to an excess mortality risk for patients treated in several eastern European countries [103]. Most of this variation was explained by disparities in public health expenditure, which determines availability and quality of pediatric renal care services. In addition, differences in a country's ability to accept and successfully treat the youngest children, who are the most complex and costly to treat, formed an additional source of disparity. Economic constraints were also associated with a lower incidence of RRT [104]. As nonacceptance to RRT implies an underestimation of ESRD 
mortality rates (as these deaths go unregistered), inequalities in mortality caused by economic constraints will be exacerbated. In addition, considerable country variation persists in transplant rates, donor source, and time on the transplant waiting list, which - given the beneficial effect of transplantation - will affect patient survival indirectly [105].

\section{Recommendations for long-term follow-up through adulthood}

The increased mortality risk of pediatric-onset ESRD remains in adulthood, with life expectancy reduced by $40-50$ years in dialysis patients and 20-30 years in transplant patients [14]. CVD is highly prevalent amongs young adults after lengthy exposure to RRT but is reversible [106-109]. Strict monitoring of CVD and intensified antihypertensive and antilipemic therapy should therefore be a priority. As most pediatric-onset ESRD patients will have received a transplant prior to transitioning to adult care, continued compliance to immunosuppression regimens is of the upmost importance, especially given that up to $53 \%$ of adolescents are noncompliant [110-112]. Moreover, due to prolonged exposure to immunosuppression in these patients, adult nephrologists should be attentive to the increased risk of infections and the development of skin cancers $10-15$ years posttransplantation.

\section{Knowledge gaps}

National and international registries for pediatric RRT have been instrumental in describing survival and establishing factors associated with mortality. However, data from middleand lower-income countries remain scarce. The forthcoming International Pediatric Nephrology Association (IPNA) registry aims to consolidate existing registry data and fill in the gaps by collecting global data [113]. Worldwide reporting of pediatric RRT is essential to determine international disparities in treatment modalities and mortality rates, increase awareness of these disparities, and provide evidence to advocate policy change and inform budgetary decisions at various levels of government.

Furthermore, although associations between mortality and various patient- and treatment-related factors have been studied in the adult RRT population, simple extrapolation of these results to children is often not valid given the differences in disease etiology and progression. Small samples sizes and a low number of adverse events often impede epidemiological research. Nonetheless, with continued support and commitment, the volume of registry data will increase over time, hopefully enabling studies to fill the knowledge gaps concerning determinants of mortality, specifically in the pediatric RRT population [114].

\section{Limitations}

Several factors limited our ability to investigate mortality risk in the pediatric RRT population. First, children with ESRD who are not accepted for RRT or who died prior to treatment initiation are not registered. Second, patients are frequently lost to follow-up in registries when transferred to adult care, precluding registration of premature death during (early) adulthood. Third, studies often focus on mortality risk of either dialysis or transplantation instead of throughout the entire RRT trajectory. Lastly, in contrast to adult patients, virtually all children with ESRD are considered transplantable, and thus long-term dialysis studies are scarce and subject to negative selection of nontransplantable patients.

\section{Summary}

- Patient survival has improved substantially over recent decades in both dialysis and transplant populations, and although the youngest patients bear the highest mortality risk, they also show the greatest improvement in survival over time.

- Patient survival is multifactorial, largely dependent on access to treatment, country health expenditure, disease etiology, age, transplant feasibility, growth failure, sex, BMI, race, and presence of comorbidities.

- Although comparisons between dialysis modalities are hindered by selection bias and residual confounding, patients initiated on PD seem to have an initial survival advantage over those initiated on HD.

- Global disparities persist in the provision of RRT and outcomes in the pediatric ESRD population, even among middle- and higher-income countries.

\section{Questions (answers are provided following the reference list)}

1. What is roughly the 5-year survival rate for an average pediatric patient starting RRT in a developed country?
a. $90 \%$
b. $80 \%$
c. $70 \%$
d. $60 \%$

2. Which patient group has seen the greatest improvement in survival over the past decade?
a. Youngest patients
b. Pubertal patients 

c. Patients with a CAKUT diagnosis
d. Patients receiving a pre-emptive transplant

3. Which patient population has an increased risk of cardiovascular mortality?
a. Black patients
b. Youngest patients
c. Hemodialysis patients
d. All of the above

4. What is roughly the 20-year survival rate for an average pediatric patient initiating RRT with a pre-emptive transplant in Europe?
a. $75 \%$
b. $80 \%$
c. $90 \%$
d. $95 \%$

5. Which factor(s) are responsible for the global disparities in treatment outcomes for children?

a. Capacity to provide RRT to the youngest patients

b. Macroeconomic constraints

c. Financial burden for patient/family

d. All of the above

\section{Compliance with ethical standards}

Conflict of interest The authors declare no competing interests.

Open Access This article is distributed under the terms of the Creative Commons Attribution 4.0 International License (http:// creativecommons.org/licenses/by/4.0/), which permits unrestricted use, distribution, and reproduction in any medium, provided you give appropriate credit to the original author(s) and the source, provide a link to the Creative Commons license, and indicate if changes were made.

\section{References}

1. Harambat J, van Stralen KJ, Kim JJ, Tizard EJ (2012) Epidemiology of chronic kidney disease in children. Pediatr Nephrol 27:363-373

2. Chavers BM, Molony JT, Solid CA, Rheault MN, Collins AJ (2015) One-year mortality rates in US children with end-stage renal disease. Am J Nephrol 41:121-128

3. Chesnaye N, Bonthuis M, Schaefer F, Groothoff JW, Verrina E, Heaf JG, Jankauskiene A, Lukosiene V, Molchanova EA, Mota C, Peco-Antić A, Ratsch I-MM, Bjerre A, Roussinov DL, Sukalo A, Topaloglu R, Van Hoeck K, Zagozdzon I, Jager KJ, Van Stralen KJ (2014) Demographics of paediatric renal replacement therapy in Europe: A report of the ESPN/ERA-EDTA registry. Pediatr Nephrol 29:2403-2410

4. Moncrief JW, Popovich RP, Nolph KD (1990) The history and current status of continuous ambulatory peritoneal dialysis. Am J Kidney Dis 16:579-584

5. Henderson LW, Besard A, Michaels A, Bluemle LWJ (1967) Blood purification by Ultrafiltration and fluid replacement (Diafiltration). Trans Am Soc Artif Intern Organs 13:216-222
6. Hothi DK, Stronach L, Sinnott K (2016) Home hemodialysis in children. Hemodial Int 20:349-357

7. Armignacco P, Lorenzin A, Neri M, Nalesso F, Garzotto F, Ronco C (2015) Wearable devices for blood purification: Principles, miniaturization, and technical challenges. Semin Dial 28:125-130

8. Wuhl E, Schaefer F (2008) Therapeutic strategies to slow chronic kidney disease progression. Pediatr Nephrol 23:705-716

9. Maiorca R, Cantaluppi A, Cancarini GC, Scalamogna A, Broccoli R, Graziani G, Brasa S, Ponticelli C (1983) Prospective controlled trial of a Y-connector and disinfectant to prevent peritonitis in continuous ambulatory peritoneal dialysis. Lancet 2:642-644

10. Sam R, Vaseemuddin M, Leong WH, Rogers BE, Kjellstrand CM, Ing TS (2006) Composition and clinical use of hemodialysates. Hemodial Int 10:15-28

11. Bruno M, Bagnis C, Marangella M, Rovera L, Cantaluppi A, Linari F (1989) CAPD with an amino acid dialysis solution: A long-term, cross-over study. Kidney Int 35:1189-1194

12. Lin FK, Suggs S, Lin CH, Browne JK, Smalling R, Egrie JC, Chen KK, Fox GM, Martin F, Stabinsky Z (1985) Cloning and expression of the human erythropoietin gene. Proc Natl Acad Sci U S A 82:7580-7584

13. Fine RN, Kohaut EC, Brown D, Perlman AJ (1994) Growth after recombinant human growth hormone treatment in children with chronic renal failure: Report of a multicenter randomized doubleblind placebo-controlled study. Genentech Cooperative Study Group J Pediatr 124:374-382

14. Kramer A, Stel VS, Tizard J, Verrina E, Rönnholm K, Pálsson R, Maxwell H, Jager KJ (2009) Characteristics and survival of young adults who started renal replacement therapy during childhood. Nephrol Dial Transplant 24:926-933

15. Halloran PF (2004) Immunosuppressive drugs for kidney transplantation. N Engl J Med 351:2715-2729

16. Rees L, Shaw V (2007) Nutrition in children with CRF and on dialysis. Pediatr Nephrol 22:1689-1702

17. Groothoff JW (2005) Long-term outcomes of children with endstage renal disease. Pediatr Nephrol 20:849-853

18. Chesney RW (2002) The development of pediatric nephrology. Pediatr Res 52:770-778

19. McDonald SP, Craig JC (2004) Long-term survival of children with end-stage renal disease. N Engl J Med 350:2654-2662

20. van der Heijden BJ, van Dijk PCW, Verrier-Jones K, Jager KJ, Briggs JD (2004) Renal replacement therapy in children: Data from 12 registries in Europe. Pediatr Nephrol 19:213-221

21. Mitsnefes MM, Laskin BL, Dahhou M, Zhang X, Foster BJ (2013) Mortality risk among children initially treated with dialysis for end-stage kidney disease, 1990-2010. JAMA 309:1921-1929

22. van Stralen KJ, Borzych-Dużalka D, Hataya H, Kennedy SE, Jager KJ, Verrina E, Inward C, Rönnholm K, Vondrak K, Warady BA, Zurowska AM, Schaefer F, Cochat P (2014) Survival and clinical outcomes of children starting renal replacement therapy in the neonatal period. Kidney Int 86:168-174

23. Carey WA, Martz KL, Warady BA (2015) Outcome of patients initiating chronic peritoneal dialysis during the first year of life. Pediatrics 136:e615-e622

24. Laskin BL, Mitsnefes MM, Dahhou M, Zhang X, Foster BJ (2014) The mortality risk with graft function has decreased among children receiving a first kidney transplant in the United States. Kidney Int 87:1-9

25. NAPRTCS Collaborative Studies NAPRTCS (2014) Annual transplant report. Available at www.naprtcs.org

26. National Institutes of Health National Institute of Diabetes and Digestive and Kidney Diseases (2015) United States Renal Data System. 2015 USRDS annual data report: epidemiology of kidney disease in the United States. Available at https://www.usrds.org/ 
27. Lin HH, Tsai C-W, Lin PH, Cheng KF, Wu HD, Wang IK, Lin C, Chen W, Huang CC (2012) Survival analysis of pediatric dialysis patients in Taiwan. Nephrology (Carlton) 17:621-627

28. National Institutes of Health National Institute of Diabetes and Digestive and Kidney Diseases (2012) United States Renal Data System, USRDS 2012 Annual Data Report: Atlas of chronic kidney disease and end-stage renal disease in the United States. Available at https://www.usrds.org/

29. Samuel SM, Tonelli MA, Foster BJ, Alexander RT, Nettel-Aguirre A, Soo A, Hemmelgarn BR (2011) Survival in pediatric dialysis and transplant patients. Clin J Am Soc Nephrol 6:1094-1099

30. Hattori M, Sako M, Kaneko T, Ashida A, Matsunaga A, Igarashi T, Itami N, Ohta T, Gotoh Y, Satomura K, Honda M, Igarashi T (2015) End-stage renal disease in Japanese children: A nationwide survey during 2006-2011. Clin Exp Nephrol 19:933-938

31. NAPRTCS (2011) NAPRTCS 2011 annual report. Available at www.naprtcs.org

32. Alexander RT, Foster BJ, Tonelli MA, Soo A, Nettel-Aguirre A, Hemmelgarn BR, Samuel SM (2012) Survival and transplantation outcomes of children less than 2 years of age with end-stage renal disease. Pediatr Nephrol 27:1975-1983

33. Bunchman TE (1995) Chronic dialysis in the infant less than 1 year of age. Pediatr Nephrol:S18-S22

34. Mekahli D, Shaw V, Ledermann SE, Rees L (2010) Long-term outcome of infants with severe chronic kidney disease. Clin J Am Soc Nephrol 5:10-17

35. Kari JA, Gonzalez C, Ledermann SE, Shaw V, Rees L (2000) Outcome and growth of infants with severe chronic renal failure. Kidney Int 57:1681-1687

36. Shooter M, Watson A (2000) The ethics of withholding and withdrawing dialysis therapy in infants. Pediatr Nephrol 14:347-351

37. Zurowska AM, Fischbach M, Watson AR, Edefonti A, Stefanidis CJ (2013) Clinical practice recommendations for the care of infants with stage 5 chronic kidney disease (CKD5). Pediatr Nephrol 28:1739-1748

38. Pollack S, Eisenstein I, Tarabeih M, Shasha-Lavski H, Magen D, Zelikovic I (2015) Long-term hemodialysis therapy in neonates and infants with end-stage renal disease: A 16-year experience and outcome. Pediatr Nephrol 31:305-313

39. Foster BJ, Dahhou M, Zhang X, Platt RW, Hanley JA (2011) Change in mortality risk over time in young kidney transplant recipients. Am J Transplant 11:2432-2442

40. Hogan J, Couchoud C, Bonthuis M, Groothoff JW, Jager KJ, Schaefer F, Van Stralen KJ (2016) Gender disparities in access to pediatric renal transplantation in Europe: Data from the ESPN/ERA-EDTA registry. Am J Transplant 16:2097-2105

41. Laster M, Soohoo M, Hall C, Streja E, Rhee CM, Ravel VA, Reddy U, Norris KC, Salusky IB, Kalantar-Zadeh K (2017) Racial-ethnic disparities in mortality and kidney transplant outcomes among pediatric dialysis patients. Pediatr Nephrol 32:685695

42. Parekh RS, Carroll CE, Wolfe RA, Port FK (2002) Cardiovascular mortality in children and young adults with end-stage kidney disease. J Pediatr 141:191-197

43. Chavers BM, Li S, Collins AJ, Herzog CA (2002) Cardiovascular disease in pediatric chronic dialysis patients. Kidney Int 62:648653

44. Mitsnefes M, Stablein D (2005) Hypertension in pediatric patients on long-term dialysis: A report of the North American pediatric renal transplant Cooperative study (NAPRTCS). Am J Kidney Dis 45:309-315

45. Flynn JT, Mitsnefes M, Pierce C, Cole SR, Parekh RS, Furth SL, Warady BA (2008) Blood pressure in children with chronic kidney disease: A report from the chronic kidney disease in children study. Hypertension 52:631-637
46. Tjaden LA, Noordzij M, van Stralen KJ, Kuehni CE, Raes A, Cornelissen EAM, O'Brien C, Papachristou F, Schaefer F, Groothoff JW, Jager KJ (2015) Racial disparities in access to and outcomes of kidney transplantation in children, adolescents, and young adults: Results from the ESPN/ERA-EDTA. Am J Kidney Dis 67:293-301

47. National Institutes of Health National Institute of Diabetes and Digestive and Kidney Diseases (2008) U.S. Renal Data System, USRDS 2008 Annual Data Report: atlas of end-stage renal disease in the United States. Available at https://www.usrds.org/

48. Sule S, Fivush B, Neu A, Furth S (2011) Increased risk of death in pediatric and adult patients with ESRD secondary to lupus. Pediatr Nephrol 26:93-98

49. Harambat J, van Stralen KJ, Espinosa L, Groothoff JW, Hulton SA, Cerkauskiene R, Schaefer F, Verrina E, Jager KJ, Cochat P (2012) Characteristics and outcomes of children with primary oxalosis requiring renal replacement therapy. Clin J Am Soc Nephrol 7:458-465

50. Wong CS, Gipson DS, Gillen DL, Emerson S, Koepsell T, Sherrard DJ, Watkins SL, Stehman-Breen C (2000) Anthropometric measures and risk of death in children with endstage renal disease. Am J Kidney Dis 36:811-819

51. Wong CS, Hingorani S, Gillen DL, Sherrard DJ, Watkins SL, Brandt JR, Ball A, Stehman-Breen CO (2002) Hypoalbuminemia and risk of death in pediatric patients with end-stage renal disease. Kidney Int 61:630-637

52. Ku E, Glidden D, Hsu CY, Portale AA, Grimes B, Johansen KL (2016) Association of Body Mass Index with patient-centered outcomes in children with ESRD. J Am Soc Nephrol 27:551-558

53. Furth SL, Hwang W, Yang C, Neu AM, Fivush BA, Powe NR (2002) Growth failure, risk of hospitalization and death for children with end-stage renal disease. Pediatr Nephrol 17:450-455

54. Furth SL, Stablein D, Fine RN, Powe NR, Fivush BA (2002) Adverse clinical outcomes associated with short stature at dialysis initiation: A report of the North American pediatric renal transplant Cooperative study. Pediatrics 109:909-913

55. $\mathrm{Ku}$ E, Fine RN, Hsu C, McCulloch C, Glidden DV, Grimes B, Johansen KL (2016) Height at first RRT and mortality in children. Clin J Am Soc Nephrol 11:832-839

56. Pruthi R, O'Brien C, Casula A, Braddon F, Lewis M, Maxwell H, Tse Y, Inward C, Sinha MD (2013) UK renal registry 15th annual report: Chapter 4 demography of the UK paediatric renal replacement therapy population in 2011. Nephron Clin Pract 123(Suppl): 81-92

57. Tsai H, Yang L, Chin T, Wang H, Liu C, Wei C, Chang J (2010) Outcome and risk factors for mortality in pediatric peritoneal dialysis. Perit Dial Int 30:233-239

58. Neu AM, Sander A, Borzych-Duzalka D, Watson AR, Vallés PG, Ha IS, Patel H, Askenazi D, Balasz-Chmielewska I, Lauronen J, Groothoff JW, Feber J, Schaefer F, Warady BA (2012) Comorbidities in chronic pediatric peritoneal dialysis patients: A report of the international pediatric peritoneal dialysis network. Perit Dial Int 32:410-418

59. Shroff R, Rees L, Trompeter R, Hutchinson C, Ledermann S (2006) Long-term outcome of chronic dialysis in children. Pediatr Nephrol 21:257-264

60. Wood EG, Hand M, Briscoe DM, Donaldson LA, Yiu V, Harley FL, Warady BA, Ellis EN (2001) Risk factors for mortality in infants and young children on dialysis. Am J Kidney Dis 37: 573-579

61. Ledermann SE, Scanes ME, Fernando ON, Duffy PG, Madden SJ, Trompeter RS (2000) Long-term outcome of peritoneal dialysis in infants. J Pediatr 136:24-29

62. Ellis EN, Pearson D, Champion B, Wood EG (1995) Outcome of infants on chronic peritoneal dialysis. Adv Perit Dial 11:266-269 
63. Hijazi R, Abitbol CL, Chandar J, Seeherunvong W, Freundlich M, Zilleruelo G (2009) Twenty-five years of infant dialysis: A single center experience. J Pediatr 155:111-117

64. Amaral S, Sayed BA, Kutner N, Patzer RE (2016) Preemptive kidney transplantation is associated with survival benefits among pediatric patients with end-stage renal disease. Kidney Int 90: $1100-1108$

65. Korevaar JC, Feith GW, Dekker FW, Van Manen JG, Boeschoten EW, PMM B, Krediet RT, NECOSAD Study Group (2003) Effect of starting with hemodialysis compared with peritoneal dialysis in patients new on dialysis treatment: A randomized controlled trial. Kidney Int 64:2222-2228

66. Chesnaye NC, Schaefer F, Groothoff JW, Bonthuis M, Reusz G, Heaf JG, Lewis M, Maurer E, Paripović D, Zagozdzon I, van Stralen KJ, Jager KJ (2016) Mortality risk in European children with end-stage renal disease on dialysis. Kidney Int 89:1355-1362

67. Vidal E, van Stralen KJ, Chesnaye NC, Bonthuis M, Holmberg C, Zurowska A, Trivelli A, Da Silva JEE, Herthelius M, Adams B, Bjerre A, Jankauskiene A, Miteva P, Emirova K, Bayazit AK, Mache CJ, Sánchez-Moreno A, Harambat J, Groothoff JW, Jager KJ, Schaefer F, Verrina E, ESPN/ERA-EDTA Registry (2016) Infants requiring maintenance dialysis: Outcomes of Hemodialysis and peritoneal dialysis. Am J Kidney Dis. doi:10. 1053/j.ajkd.2016.09.024

68. Chang HJ, Han KH, Cho MH, Park YS, Kang HG, Cheong HI, Ha IS (2014) Outcomes of chronic dialysis in Korean children with respect to survival rates and causes of death. Korean J Pediatr 57: 135-139

69. Van De Luijtgaarden MWM, Jager KJ, Segelmark M, Pascual J, Collart F, Hemke AC, Remón C, Metcalfe W, Miguel A, Kramar R, Aasarød K, Abu Hanna A, Krediet RT, Schön S, Ravani P, Caskey FJ, Couchoud C, Palsson R, Wanner C, Finne P, Noordzij M (2016) Trends in dialysis modality choice and related patient survival in the ERA-EDTA registry over a 20 -year period. Nephrol Dial Transplant 31:120-128

70. van de Luijtgaarden MWM, Noordzij M, Stel VS, Ravani P, Jarraya F, Collart F, Schön S, Leivestad T, Puttinger H, Wanner C, Jager KJ (2011) Effects of comorbid and demographic factors on dialysis modality choice and related patient survival in Europe. Nephrol Dial Transplant 26:2940-2947

71. Weinhandl ED, Foley RN, Gilbertson DT, Arneson TJ, Snyder JJ, Collins AJ (2010) Propensity-matched mortality comparison of incident hemodialysis and peritoneal dialysis patients. J Am Soc Nephrol 21:499-506

72. Lukowsky LR, Mehrotra R, Kheifets L, Arah OA, Nissenson AR, Kalantar-Zadeh K (2013) Comparing mortality of peritoneal and hemodialysis patients in the first 2 years of dialysis therapy: A marginal structural model analysis. Clin J Am Soc Nephrol 8:619-628

73. Mehrotra R, Chiu Y-W, Kalantar-Zadeh K, Bargman J, Vonesh E (2011) Similar outcomes with hemodialysis and peritoneal dialysis in patients with end-stage renal disease. Arch Intern Med 171: $110-118$

74. Stokes JB (2012) Peritoneal dialysis is not a superior therapy to hemodialysis: A comparison. Blood Purif 33:160-164

75. Noordzij M, Jager KJ (2014) Patient survival on dialysis in Korea: A different story? Kidney Int 86:877-880

76. National Institutes of Health National Institute of Diabetes and Digestive and Kidney Diseases (2011) U.S. Renal Data System, USRDS 2011 Annual Data Report: Atlas of chronic kidney disease and end-stage renal disease in the United States. Available at https://www.usrds.org/

77. Bargman JM, Thorpe KE, Churchill DN (2001) Relative contribution of residual renal function and peritoneal clearance to adequacy of dialysis: A reanalysis of the CANUSA study. J Am Soc Nephrol 12:2158-2162
78. Liao C-T, Chen Y-M, Shiao C-C, Hu F-C, Huang J-W, Kao T-W, Chuang H-F, Hung K-Y, Wu K-D, Tsai T-J (2009) Rate of decline of residual renal function is associated with all-cause mortality and technique failure in patients on long-term peritoneal dialysis. Nephrol Dial Transplant 24:2909-2914

79. Guzzo I, Mancini E, Kengne Wafo S, Ravà L, Picca S (2009) Residual renal function and nutrition in young patients on chronic hemodialysis. Pediatr Nephrol 24:1391-1397

80. Chadha V, Blowey DL, Warady BA (2001) Is growth a valid outcome measure of dialysis clearance in children undergoing peritoneal dialysis? Perit Dial Int 21(Suppl 3):S179-S184

81. Borzych D, Rees L, Ha IS, Chua A, Valles PG, Lipka M, Zambrano P, Ahlenstiel T, Bakkaloglu SA, Spizzirri AP, Lopez L, Ozaltin F, Printza N, Hari P, Klaus G, Bak M, Vogel A, Ariceta G, Yap HK, Warady BA, Schaefer F, International Pediatric PD Network (IPPN) (2010) The bone and mineral disorder of children undergoing chronic peritoneal dialysis. Kidney Int 78:1295-1304

82. Wright S, Klausner D, Baird B, Williams ME, Steinman T, Tang H, Ragasa R, Goldfarb-Rumyantzev AS (2010) Timing of dialysis initiation and survival in ESRD. Clin J Am Soc Nephrol 5:18281835

83. Korevaar JC, Jansen MA, Dekker FW, Jager KJ, Boeschoten EW, Krediet RT, Bossuyt PM (2001) When to initiate dialysis: Effect of proposed US guidelines on survival. Lancet 358:1046-1050

84. Lee J, An JN, Hwang JH, Kim Y-L, Kang S-W, Yang CW, Kim NH, Oh YK, Lim CS, Kim YS, Lee JP (2014) Effect of dialysis initiation timing on clinical outcomes: A propensity-matched analysis of a prospective cohort study in Korea. PLoS One 9:e105532

85. Atkinson MA, Oberai PC, Neu AM, Fivush BA, Parekh RS (2010) Predictors and consequences of higher estimated glomerular filtration rate at dialysis initiation. Pediatr Nephrol 25:11531161

86. Cooper BA, Branley P, Bulfone L, Collins JF, Craig JC, Fraenkel MB, Harris A, Johnson DW, Kesselhut J, Li JJ, Luxton G, Pilmore A, Tiller DJ, Harris DC, Pollock CA (2010) A randomized, controlled trial of early versus late initiation of dialysis. N Engl J Med 363:609-619

87. Groothoff JW, Gruppen MP, Offringa M, Hutten J, Lilien MR, Van De Kar NJ, Wolff ED, Davin JC, Heymans HS (2002) Mortality and causes of death of end-stage renal disease in children: A Dutch cohort study. Kidney Int 61:621-629

88. Vogelzang JL, van Stralen KJ, Jager KJ, Groothoff JW (2013) Trend from cardiovascular to non-cardiovascular late mortality in patients with renal replacement therapy since childhood. Nephrol Dial Transplant 28:2082-2089

89. Rama I, Grinyó JM (2010) Malignancy after renal transplantation: The role of immunosuppression. Nat Rev Nephrol 6:511-519

90. Bartosh SM, Leverson G, Robillard D, Sollinger HW (2003) Long-term outcomes in pediatric renal transplant recipients who survive into adulthood. Transplantation 76:1195-1200

91. Smith J, Martz K, Blydt-Hansen TD (2013) Pediatric kidney transplant practice patterns and outcome benchmarks, 1987 - 2010 : A report of the North American pediatric renal trials and collaborative studies. Pediatr Transplant 17:149-157

92. Webster AC, Craig JC, Simpson JM, Jones MP, Chapman JR (2007) Identifying high risk groups and quantifying absolute risk of cancer after kidney transplantation: A cohort study of 15183 recipients. Am J Transplant 7:2140-2151

93. Ploos van Amstel S, Vogelzang JL, Starink MV, Jager KJ, Groothoff JW (2015) Long-term risk of cancer in survivors of pediatric ESRD. Clin J Am Soc Nephrol 10:2198-2204

94. Luyckx VA, Naicker S, McKee M (2013) Equity and economics of kidney disease in sub-Saharan Africa. Lancet 382:103-104

95. Sinha A, Bagga A (2014) Maintenance dialysis in developing countries. Pediatr Nephrol:211-219 
96. Liyanage T, Ninomiya T, Jha V, Neal B, Patrice HM, Okpechi I, Zhao MH, Lv J, Garg AX, Knight J, Rodgers A, Gallagher M, Kotwal S, Cass A, Perkovic V (2015) Worldwide access to treatment for end-stage kidney disease: A systematic review. Lancet 385:1975-1982

97. Harambat J, Ekulu PM (2016) Inequalities in access to pediatric ESRD care: A global health challenge. Pediatr Nephrol 31:353358

98. Miller MEY, Williams JA (2009) Chronic renal failure in Jamaican children - An update (2001 - 2006). West Indian Med J 58:231-234

99. Asinobi AO, Ademola AD, Ogunkunle OO, Mott SA (2014) Paediatric end-stage renal disease in a tertiary hospital in south West Nigeria. BMC Nephrol 15:25

100. Mong Hiep TT, Janssen F, Ismaili K, Khai Minh D, Vuong Kiet D, Robert A (2008) Etiology and outcome of chronic renal failure in hospitalized children in ho chi Minh City, Vietnam. Pediatr Nephrol 23:965-970

101. Gulati S, Mittal S, Sharma RK, Gupta A (1999) Etiology and outcome of chronic renal failure in Indian children. Pediatr Nephrol 13:594-596

102. el Nahas AM, Bello AK (2010) Chronic kidney disease: The global challenge. Lancet 365:331-340

103. Chesnaye NC, Schaefer F, Bonthuis M, Holman R, Baiko S, Baskın E, Bjerre A, Cloarec S, Cornelissen EAM, Espinosa L, Heaf J, Stone R, Shtiza D, Zagozdzon I, Harambat J, Jager KJ, Groothoff JW, van Stralen KJ (2017) Mortality risk disparities in children receiving chronic renal replacement therapy for the treatment of end-stage renal disease across Europe: An ESPN-ERA/ EDTA registry analysis. Lancet 6736:1-10

104. Chesnaye NC, Schaefer F, Groothoff JW, Caskey FJ, Heaf JG, Kushnirenko S, Lewis M, Mauel R, Maurer E, Merenmies J, Shtiza D, Topaloglu R, Zaicova N, Zampetoglou A, Jager KJ, Van Stralen KJ (2015) Disparities in treatment rates of paediatric end-stage renal disease across Europe: Insights from the ESPN/ ERA-EDTA registry. Nephrol Dial Transplant 30:1377-1385

105. Harambat J, Van Stralen KJ, Schaefer F, Grenda R, Jankauskiene A, Kostic M, Macher M, Maxwell H, Puretic Z, Raes A, Rubik J, Sørensen S, Toots Ü, Topaloglu R, Tönshoff B, Verrina E, Jager KJ (2013) Disparities in policies, practices and rates of pediatric kidney transplantation in Europe. Am J Transplant 13:2066-2074

106. Vogelzang JL, Heestermans LWAA, van Stralen KJ, Jager KJ, Groothoff JW (2013) Simultaneous reversal of risk factors for cardiac death and intensified therapy in long-term survivors of paediatric end-stage renal disease over the last 10 years. Nephrol Dial Transplant 28:2545-2552

107. Dobrowolski LC, van Huis M, van der Lee JH, Peters Sengers $\mathrm{H}$, Liliën MR, Cransberg K, Cornelissen M, Bouts AH, de Fijter JW, Berger SP, van Zuilen A, Nurmohamed SA, Betjes MHG, Hilbrands L, Hoitsma AJ, Bemelman FJ, Krediet P, Groothoff JW (2016) Epidemiology and management of hypertension in paediatric and young adult kidney transplant recipients in The Netherlands. Nephrol Dial Transplant 31:19471956

108. Groothoff JW, Gruppen MP, Offringa M, de Groot E, Stok W, Bos WJ, Davin JC, Lilien MR, Van de Kar NC, Wolff ED, Heymans HS (2002) Increased arterial stiffness in young adults with endstage renal disease since childhood. J Am Soc Nephrol 13:29532961

109. Gruppen MP, Groothoff JW, Prins M, van der Wouw P, Offringa M, Bos WJ, Davin JC, Heymans HS (2003) Cardiac disease in young adult patients with end-stage renal disease since childhood: A Dutch cohort study. Kidney Int 63: 1058-1065

110. Rianthavorn P, Ettenger RB, Malekzadeh M, Marik JL, Struber M (2004) Noncompliance with immunosuppressive medications in pediatric and adolescent patients receiving solid-organ transplants. Transplantation 77:778-782

111. Van Arendonk KJ, James NT, Boyarsky BJ, Garonzik-Wang JM, Orandi BJ, Magee JC, Smith JM, Colombani PM, Segev DL (2013) Age at graft loss after pediatric kidney transplantation: Exploring the high-risk age window. Clin J Am Soc Nephrol 8: 1019-1026

112. Watson AR (2000) Non-compliance and transfer from paediatric to adult transplant unit. Pediatr Nephrol 14:469-472

113. IPNA (2017) IPNA website. https://www.ipna-online.org/. Accessed 6 Feb 2017

114. Liu FX, Rutherford P, Smoyer-Tomic K, Prichard S, Laplante S (2015) A global overview of renal registries: A systematic review. BMC Nephrol 16:1-10

\section{Answers}

1. a; 2. a; 3. d; 4. c; 5. d 